\title{
3
}

\section{Testing paths in shamanic performances among the northern Amis of Taiwan}

\author{
Yi-tze Lee
}

\section{Introduction}

The Amis people are the single largest group of indigenous people in Taiwan. With a population of roughly 250,000 people living mostly in the eastern part of Taiwan, the Amis are famous for their agricultural rituals led by groups of shamans. These rituals include millet sowing, weeding, field cleaning, pest control, harvesting, storage and, finally, fishing activities that conclude the rice cycle. While rituals give meaning to the daily lives of the Amis, changes have occurred in these rituals owing to three main causes: 1 ) because of migration and the relocation of animals related to ritual activities, 2) because of changes in subsistence strategies, and 3) because of urbanisation that limits ritual access and agricultural use on traditional territory. Together, these three factors have brought about a 'deterritorialisation' of the Amis people on their own land and so have reshaped their ritual landscape. ${ }^{1}$ The most prominent yearly rituals include Midiwai, the ritual to announce millet sowing at the end of December; Misatuligun, the ritual for field cleaning in March; Mivava,

\footnotetext{
1 By legal definition of the Taiwan Government, there is no 'traditional territory reservation area' for the Amis since they lived with Han people during the Japanese colonial period.
} 
the pest-control ritual in April; and Miladis, the fishing ritual that ends the rice cultivation cycle in June (see Table 3.1). These rituals reflect the significant relationship between people and animals in the landscape.

The seasonal cycle is based on the millet-planting schedule. In early February, a ritual is carried out after millet plants start to shoot. This weeding ritual called Mivalidas is carried out when every household has finished preparing its farming tools. During the process of ritual weeding, villagers tie weeds into stacks and make the collective work in the field mimic a game of 'tug-of-war'. The next farming ritual is called Mivava, in April. 'Vava' is a broom made from the leaves and stems of the areca palm. A leaf stem is tied with betel nuts wrapped in it. Villagers line up to follow the shamans, who throw betel nuts and rice wine into the air for ritual cleansing and to chase away pests and hungry spirits. Mivava is an important ritual for environmental protection of the growing millet while the ritual process identifies both sparrows (ciruciru) and hungry ghosts (tagenawan) as pests. Millet needs to be harvested around May and the ritual for post-harvest storage is called Mianan (anan is a ritual term for 'granary' in Amis). When Mianan is carried out, the deceased ancestors of a family are summoned to enjoy and bless the harvest and to protect the harvest in storage. Nowadays, Mianan is held in mid-June when the rice crop is harvested and husked for storage.

Table 3.1 Yearly ritual cycle of Nangshi ${ }^{2}$ Amis

\begin{tabular}{|c|c|c|c|c|c|c|c|}
\hline Month & December & January & February & \multicolumn{2}{|c|}{ March } & \multicolumn{2}{|l|}{ April } \\
\hline Season & \multicolumn{3}{|c|}{ Kasi'nawan (Cold season) } & \multicolumn{4}{|c|}{ Ka'Oladan (Rainy season) } \\
\hline $\begin{array}{l}\text { Ritual } \\
\text { event }\end{array}$ & \multicolumn{2}{|l|}{ Midiwai } & \multicolumn{3}{|c|}{ Misatuligun } & \multicolumn{2}{|l|}{ Mivava } \\
\hline Activities & \multicolumn{2}{|c|}{ Millet planting } & \multicolumn{3}{|c|}{$\begin{array}{l}\text { Weeding, growing } \\
\text { yams }\end{array}$} & \multicolumn{2}{|c|}{ Dispelling pests and ghosts } \\
\hline Month & May & & June & July & August & September & October November \\
\hline Season & \multicolumn{4}{|c|}{ Kacidalan (Dry and sunny) } & \multicolumn{2}{|c|}{$\begin{array}{l}\text { Kabaliusan } \\
\text { (Typhoon) }\end{array}$} & Kafaliwan (Windy) \\
\hline $\begin{array}{l}\text { Ritual } \\
\text { event }\end{array}$ & \multicolumn{2}{|l|}{ Mianan } & Miladis & \multicolumn{2}{|c|}{ Miadop } & Malalikid & Mirecuk \\
\hline Activities & \multicolumn{2}{|c|}{$\begin{array}{l}\text { Harvest millet } \\
\text { and restore }\end{array}$} & $\begin{array}{l}\text { Fishing } \\
\text { ritual }\end{array}$ & \multicolumn{2}{|c|}{ Hunting } & $\begin{array}{l}\text { Harvest } \\
\text { festival }\end{array}$ & Shamanic rituals \\
\hline
\end{tabular}

2 'Nangshi' is the geographic term for the area where the northern Amis people live. It covers the current administrative regions of Huaien City, Chian County and Shinchen County. 


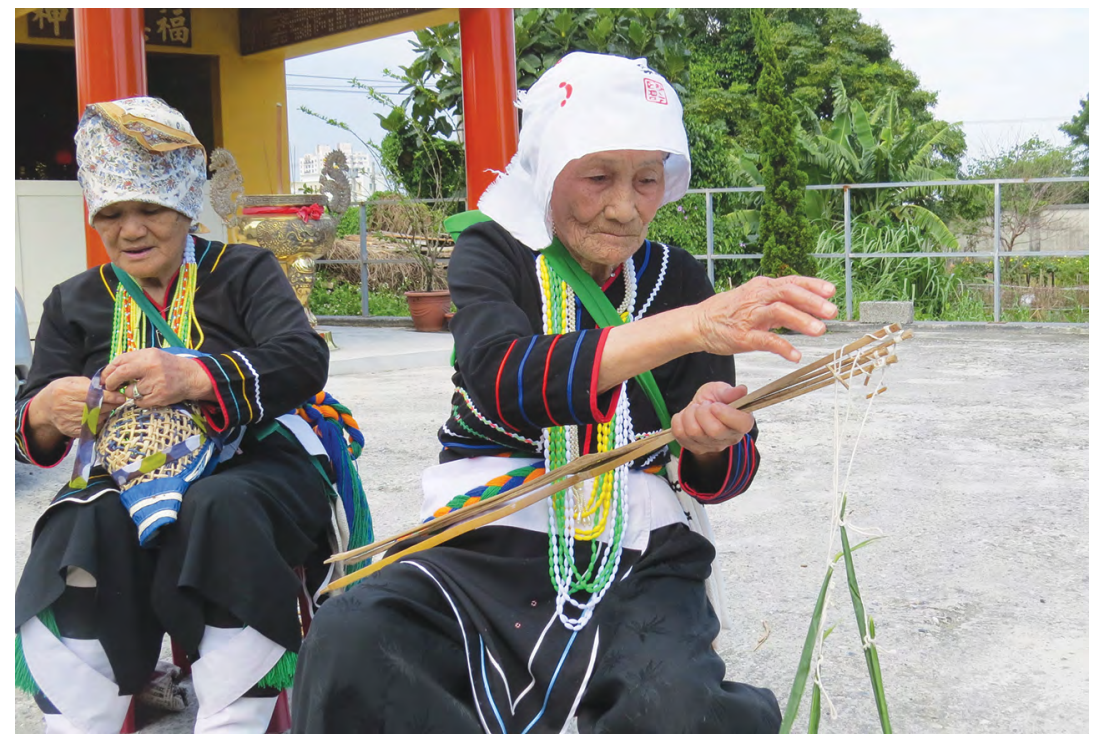

Plate 3.1 Two shamans prepare a male bird trap for the Misatuligun ritual

Photo: Yi-tze Lee.

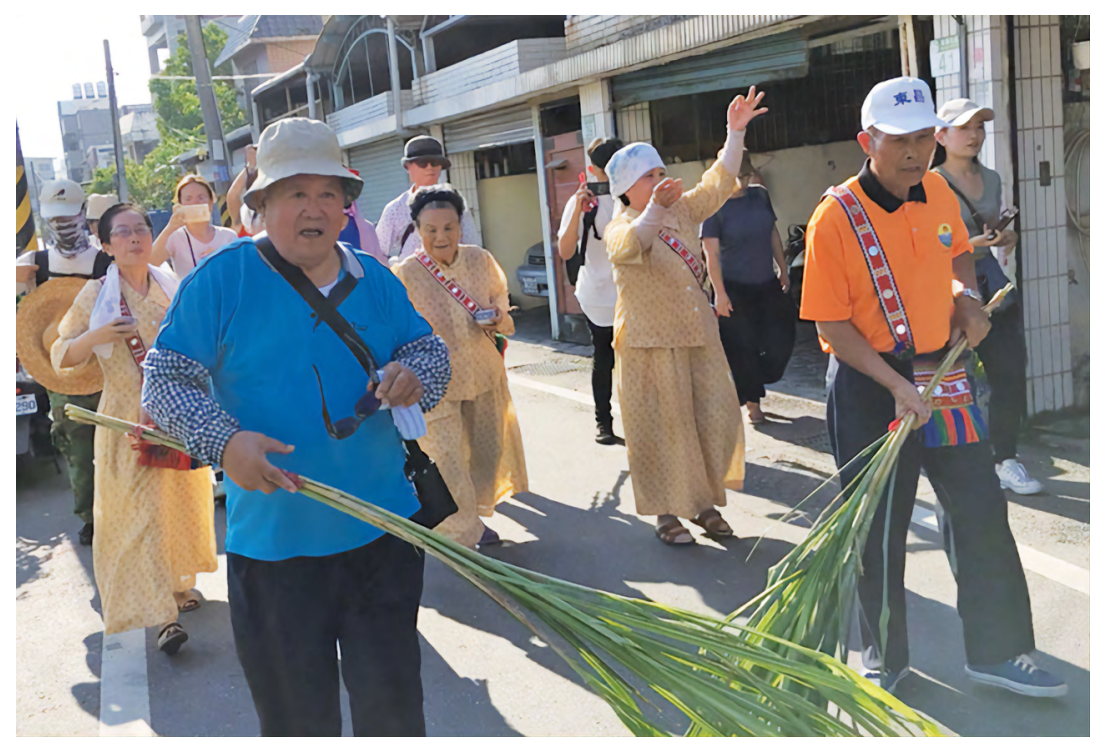

Plate 3.2 During the Mivava ritual, elders and shamans symbolically sweep away filth to reorder the main border path of the village. One shaman holds an invisible calai thread

Photo: Yi-tze Lee. 
Women are thought to be the origin of the family and they inherit the natal family's property. One linguistic expression reinforces the notion that a woman is the core element of a family. The Amis word maran-ina$a i$, which refers to members of the same family, comes from the root ina, which means 'mother'. A man marries out of his natal family but retains greater rights in its affairs than in the family into which he marries. This is also reflected in the spiritual world: the guardian spirits to whom Amis shamans turn are a group of female spirits called dongi. Dongi are the guides for the sikawasai shamans. The duas ('ancestors and deceased family members') can only be summoned home if the dongi are pleased and the calai (the invisible threads they provide) are tested. Although there are both male and female shamans in Amis tradition, as a result of changes in modern life, male shamans are no longer considered as powerful as their female counterparts. At present, there are no male shamans in Dongchang village, where I conducted my fieldwork.

Contemporary Amis ritual activities have become a new arena for cultural revitalisation: the format of rituals still follows the traditional cycle, but rituals now combine the worship of Chinese deities using incense and firecrackers with new sources of community solidarity promoted by government political mobilisation efforts. Through repeated ritual practice, symbolic paths in the ritual landscape are constantly reshaped and reconstructed, drawing new boundaries. In contemporary activities, the dialectic meaning of paths and the way they are tested via the use of symbolic threads can shed light on how ritual landscapes are constructed through memories of physical performances, but also through the incorporation of a political agenda. This transition occurring in the ritual landscape and the changing meanings of paths whose authenticity is tested are a consequence of Amis-Han historical interaction, connected to an understanding of the colonial legacy of ethnic relationships.

This chapter reflects on how symbolic indicators of paths and pathtesting illustrate the dialectic relationship that exists in Amis ritual between authority and authenticity. The invisible threads known as calai-symbolising authentic paths to the spirit world—serve as embedded vectors of bodily orientation in rituals as well as a means to resolve conflict and bring about restoration of both spiritual and ethnic boundaries. In a tentative and cautious ritual process, invisible threads of calai are sought from the dongi and then carefully protected by shaman leaders. This process also reflects the Amis view that women represent the 
inner core of the household while men are actors in the outside world of mountains and rivers. To provide a background understanding of the use of paths and their testing in rituals, I will start with the historical transition and migration of Amis people.

\section{Amis migration routes and livelihood transition}

Among Taiwanese indigenous people, Amis are the ones who undertake gardening and farming as their subsistence strategy, living most closely to the settler regions of Han Chinese. For a long time, the Amis sustained themselves by hunting, fishing, gathering wild vegetables and cultivating millet as their major food sources. They developed a sophisticated cycle of ritual practices in harmony with seasonal rhythms. This traditional lifestyle changed greatly during the Japanese colonial period (1895-1945), when the Amis were forced to adopt rice cultivation and work as coolies. A major change in the colonial period was the introduction of Japonica rice and other crops. A change to two harvests each year provided a more secure food supply. At the same time, the Amis were mobilised into a wartime supply system, which demanded more efficient planting, forced labour to build railways and harbours and heavy taxation (Ka 1995; Tsurumi 1977). The Amis also faced conflicts over religion and modern formal education. Traditional connections with the natural world began to dissolve and subsequent generations of Amis were gradually alienated from their forefathers' connections with nature. Rituals, however, continue to impart the wisdom handed down from the elders.

\section{The gendered conception of space}

The traditional spatial conception of the Amis is represented by the different corners of a house and is based on the division of labour among men and women. Different productive tools are placed in different corners of the house depending on gender associations. The Amis also believe some dominant spirits dwell in particular directions. They are all represented in Figure 3.1. 


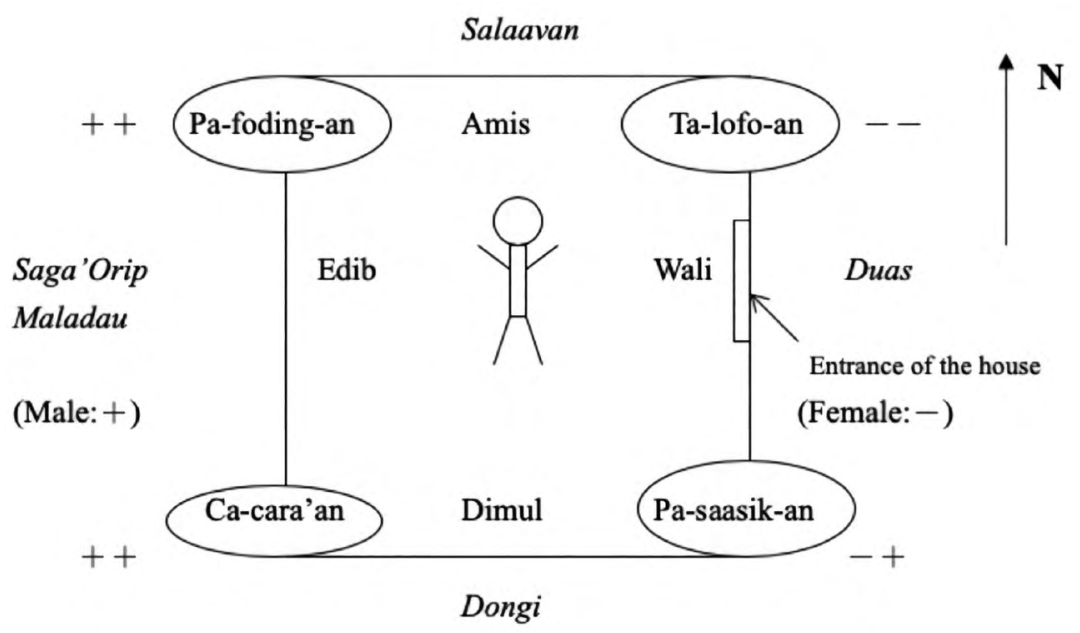

Figure 3.1 The Amis's spatial conception of the house and the location of spirits

Source: Drawn by the author.

\section{Ritual directions}

Amis, Dimul, Edib and Wali define the directions north, south, west and east.

- East is the direction of Duas (ancestors). According to the village origin legend, the ancestors took a boat and came from the east by sea.

- The Dongi in the south is the guardian goddess of the human body. The Amis sleep and sit facing the south during a period of healing to receive the blessing from the Dongi.

- Saga'orip in the west is the spirit of crop growth. Maladau, who dwells in the west, is the god that men worship for hunting; to the west side of the village are mountains.

- Salaavan in the north indicates the place where the souls of the villagers who die a bad death or die outside the village go. This direction is also where Amis people came from historically because Dongchang is the northernmost tribe among the Amis. 


\section{Four special corners}

- Pa-foding-an: This corner is the place in the house where men put their fishing net (from foding: 'fish'). Women are forbidden to touch the fishing net and cannot come into this corner during critical phases of farm work.

- Ca-cara'an: Cala (or Cara) refers to the mandible of the mountain pig. This is the traditional place where males put the mandibles of wild animals and worship the spirits of animals after hunting. The clay pot for men's worship, called dewas, is stored here. The taboo against women entering this corner is even stricter than the taboo for the corner in which the fishing net is hung. This is a prime male locality.

- Pa-saasik-an: Saasik means a bunch of straw and refers to the broom made from straw. This is the place where the broom, dustpan and farming tools are stored. This is also the place where some clans in the village honoured heads taken in headhunting when that practice was still conducted. In ritual activities, it signifies 'exiting or sweeping out'. The corner is ambiguous in regard to gender because both women's (farming and cleaning) tools and men's worship activity (for the head) are associated with this corner.

- Pa-lofo-an: Lofo means 'granary'. It can refer to the female clay pot for worship, which is called sivanohai. Women's pottery and the utensils used for family rituals are stored in this corner. The family granary is built in the northeast and grain is stored there after the harvest. Men are not allowed to do such work. This is a prime female locality.

According to the symbolic arrangements, men are associated with the west and women with the east. Besides this east-west dichotomy, there is another distinction: men are associated with uncultivated fields, forest land and coastal areas and women are associated with the house. Hunting and fishing are conducted far away from the house and are usually carried out by men of the same age set; women are forbidden to touch or get close to the western corners of the house where male implements are kept. In contrast, the east side of the house primarily represents female activities, such as farming, grain storage and house sweeping.

This spatial concept is an 'uneven' opposition: women are not allowed to enter men's corners of the house while men can sometimes enter a women's corner if women are not available-a superiority of 'maleness' in a ritual sense, but later changed since male shamans are not available 
nowadays. From the evidence of the arrangement of tools in the house, this spatial conception endows rituals with meaning: shamans turn to a specific direction for particular rituals as well in the practice of healing. This spatial conception is also critical in the use and arrangement of symbolic calai on ritual occasions. I will now examine the functional meaning of calai in Amis rituals.

\section{Calai: A road offered and tested before being taken}

For Amis shamans, the calai is a critical tool in conducting rituals. Calai is the ritual term used for a road or path. It can be transformed into a healing tool and a means of demarcating boundaries. It is described as a shining string that resembles the thread of a spider's web. The calai is an invisible but important tool used by Amis shamans in rituals to create a connection between themselves and the spiritual world.

There are three senses of the term calai that need to be explored. First, calai refers to an invisible thread that a shaman holds in her hand while engaged in rituals. When shamans call upon the ancestors, the calai represents a symbolic thread that links the mundane with the sacred world. A shaman requests the calai, which is given by the female guardian dongi spirits who dwell in the southern world. A typical daily ritual, for example, the healing practice called badevu (literally, 'searching for the soul'), starts with the shaman offering rice liquor as she prays to the ancestors; she then turns to the south, chanting to the dongi spirits to obtain their blessings and a precious calai. Once the leading shaman has successfully acquired a calai from the south, she will take care of the sacred thread and use this invisible calai as a tool to access locations where the patient's soul has been hidden. The whole process is performed in a mime-like drama with the recitation of names revealing to the patient's family the presence of deities and guardian goddesses. Here the calai serves as a compass directing the shaman to different places in the spiritual world.

Second, calai can also refer to a 'path' and is used interchangeably with the Amis word for 'path', lalan. A path or road is part of the infrastructure of the mundane world but may be disguised in the Amis spiritual world. In the latter, access to a path cannot be taken for granted and needs to be tested over and over again to ensure its authenticity. This takes the form 
of an extended verbal exchange known as baceva-an articulated quest to determine the genuineness of the path. The calai is a path leading to the spiritual world, but the ancestors may provide misleading directions, forcing the shamans to test their authenticity. A shaman needs to examine the calai whenever she receives a 'spiritual road' from the guardian spirit, dongi. This examination is to ensure the safety of the shaman who must walk this path, thus demonstrating her spiritual power in public. Here the calai is a probe for power and authenticity.

Third, a calai can be transformed during a ritual from the symbol of a road to that of a border. In testing the authenticity of a calai during a ritual performance, the presence of a clear border and a clean body is constantly stressed. Shamans and ritual participants have to be cautious when transitioning between spiritual and earthly activities. At a critical moment, the calai can be transformed from a path to a cleansing tool to assess the boundaries of the body and the village. The calai thus offers a remedy for distorted or broken boundaries that occur after contacts with non-Amis or in living a contemporary lifestyle in which traditions are no longer observed. Here the calai is an indicator of, and possible remedy for, boundary transgressions.

In these three aspects of calai, we see its transformative nature and multiple functions. Feelings toward the spiritual are ambivalent, requiring delicacy, respect, awe, caution and fear-all at the same time. Calai in ritual represents paths for the Amis, whether or not, after scrutiny, these are taken. It shows how the Amis interpret their ethical relations and the boundaries they create in daily experience. I want to delve now into examples of this ritual landscape as well as the environmental changes that have occurred in it.

In the case of the Amis, an awareness of 'filth' is emphasised in the process of dealing with the 'spiritual body' of the $\mathrm{dead}^{3}$ and the repetitive selfcleaning actions of the shaman. The symbolic cleansing therefore prevents

3 Thomas Csordas (1990: 5) directs attention to the primacy of the body by stressing that the 'body is not an object to be studied in relation to culture but is to be considered as the subject of culture, or in other words as the existential ground of culture' (italics in the original). Csordas also notes that to collapse the dualities of perception and practice, the body itself has to be a unitary concept, not opposed to the principle of mind. Body is thus the hinge of the notion of preobjective and habitus (Csordas 1990: 8). 
any feelings of danger and unease. ${ }^{4}$ While filth is dealt with by a process of knife-cutting or calai-healing, a sense of potential harm is created by the shaman's actions. This sense of a contaminable body and wandering soul hence becomes the background of the whole funeral, embodied in the shaman's performances.

\section{Baceva: Testing and healing}

A notion that links the use of calai with spiritual power and healing is baceva. Baceva can mean either 'to test' or 'to deceive' (for the sake of self-protection). ${ }^{5}$

The importance of baceva is related to the shamanic use of calai. On ritual occasions, in requesting a spiritual road, shamans invariably take the first calai given to them by the dongi, but then return the threads to them with symbolic gestures. They again request a calai and examine the spiritual thread carefully. Usually it takes at least two or three tests to find the correct calai. By their performance, they show to the public and to family members that what they have finally received is the correct calai for the event. This is the baceva process in requesting spiritual tools.

On the occasion of a funeral, experienced shamans enter the yard of the house of the bereaved family 'to call back the soul of the dead'. The shamans who do soul-calling are also the leaders of the feast for spirits. They cannot be lineal relatives of the dead person. According to the Amis, if a shaman officiated at the funeral of one of her lineal relatives, the kawas ('spirits') would laugh at her or cheat her (in Amis: a baceva $d u$ kawas) for the ceremony. Moreover, the spirit of the dead would 'feel

4 In the funeral ritual, after the spiritual feast for the dead and ancestors, shamans repetitively cleanse the materials used for worship before they are stored by family members; even the ground on which they have been standing has to be cleaned several times with hand gestures.

5 I can provide an example of the notion of baceva from my personal experience in the field. While I was staying in the village, I asked many times about the exact date of the biannual ancestor-visiting ritual (tala duas; literally, 'going to the place of ancestors'), so I could prepare in advance. After being bothered by my repeated questions, my brother-in-law said to me: 'Well, the time is up so we can go catch fish soon!' I was totally perplexed by his answer, since I knew that catching fish referred to the end of a ritual, but the actual ritual had not yet happened! Several days later, I returned to his house and asked my brother-in-law why he had mentioned catching fish when the tala duas ritual had not occurred. He looked at me as if I had not understood him and replied: 'You know, we cannot speak of the date too early even if we have decided on it since the kawas-spirits may be listening! The kawas and our ancestors will laugh at us for our foolishness and arrogance. We need to give them the wrong answer for our own protection. Baceva du kawas, remember?' I then realised that I did not practise baceva as well as the locals even though I knew the process of the ritual.

6 In Amis, kawas is a general term for spirits. 
shame' (mangudu) and not show up during the feast. Notably, a funeral is a ritual that mediates between the impurity of the deceased and the sacredness of the ancestors. Thus, a shaman whose lineal relative has recently died, and who is therefore tinged with impurity, cannot serve to call the dead nor can a shaman who has just undergone his or her bafafui ritual (re-initiation rite) officiate in the soul-calling ritual because the impurity of the funeral will make the shaman sick. ${ }^{7}$

In performing a search for the soul, the shaman tosses out an invisible calai to guide the dead and to keep the shaman herself away from the kawas and avoid contamination from direct contact. After finding the soul, the shaman tears off a piece of banana leaf attached to the calai in her hand and throws it in the direction of the place where she found the soul. This act is meant to 'reinstate the boundaries' separating the human and spiritual worlds after the shaman's intrusion in search of the soul. Before letting the soul reunite with the body, the shaman has to shave the filth off the soul with a knife and, literally, 'cut off the ill part of the soul and throw it back to the spiritual world.

On the one hand, the calai represents the road to the spiritual world, but it needs repeated testing to provide reassurance before it can be used to lead to power and perform authentic healing. On the other hand, the calai provides a precarious connection between the human and spiritual worlds, as well as establishing the boundaries of the family and the village and between life and death.

7 An incident during my fieldwork demonstrates the ambivalence of Amis shamans towards the dead. One of the only two male shamans of the village died. Unfortunately, the most experienced and powerful shaman had just lost her adopted daughter, so she could not lead the ritual although other shamans really thought she should: 'Her voice is the clearest and most powerful one.' On the day of the burial, the shamans gathered to pay their respects to the dead. A senior shaman walked out immediately after the indoor blessing for the soul-calling ritual, trying to avoid being selected as the leader of the ritual. The most experienced shaman ran out after the first shaman and tried to convince her to be the leader. Later I realised that the senior shaman also worshipped Taiwanese Daoist gods in her family. According to her, leading the funeral ritual would have broken her fast for the worship and lowered her ability to connect with the Taiwanese gods. But, in the end, she agreed to lead the soul-calling ritual. 


\section{Changes in ritual landscapes: Environmental shifts in contemporary settings}

For Taiwan's indigenous peoples, there have been changes in rituals and their relationship with particular species in the construction of particular paths. Environmental shifts in the paths have included changes in subsistence activities, increasing urbanisation and investment in political initiatives. Liu (2007) has discussed the meaning of rice and deer as representations of gender divisions among the Kavalan and Amis people. The ritual pair is an emblem of reproductive dynamics: deer resemble men and rice resembles women. Hunting took place after harvest and shamans provided the symbolic path for Amis men when they returned from their hunting activities. When lowland deer were exterminated through commercial hunting, the ritual species shifted to a rooster since a white rooster is sacrificed to Maladaw, the protective deity of men, who is said to ride on a white pheasant. This was an 'environmental shift' in a ritual path. Commercial farming and the animal trade have brought about other important environmental shifts. Hu (2007) has discussed how the giant Magellan birdwing butterfly (Troides magellanus) of Orchid Island was commercialised and became an economic trophy product. Similarly, Lo (2010) has discussed the way Atolan Amis women have taken action to protect their clam-gathering grounds as a protest against the illegal construction of a tourist resort on their traditional territory. Actions with ritual meaning have been used in a struggle for political rights and economic wellbeing. Relationships between species and the ritual landscape have consequences for historical discourse, symbolic boundaries and action networks.

I examine three cases of the use of the idea of a path in different Amis ritual settings and consider the symbolic meanings of these practices as changes in power relationships and struggles for recognition. These cases will focus on the Mivava pest-dispelling ritual, the Miasik house-cleansing ritual and the Mirecuk shamanic power rejuvenation ritual. I intend to demonstrate how vital ritual actions are linked to 'path-finding, 'bordermaking' and 'infrastructure renewal' in Amis religious practice. The inner meaning of Amis cultural heritage has been sustained even though the original physical locations and materials have gradually become unavailable. In all these performances, the calai as a symbolic path is the focus of a continuous struggle for power. 


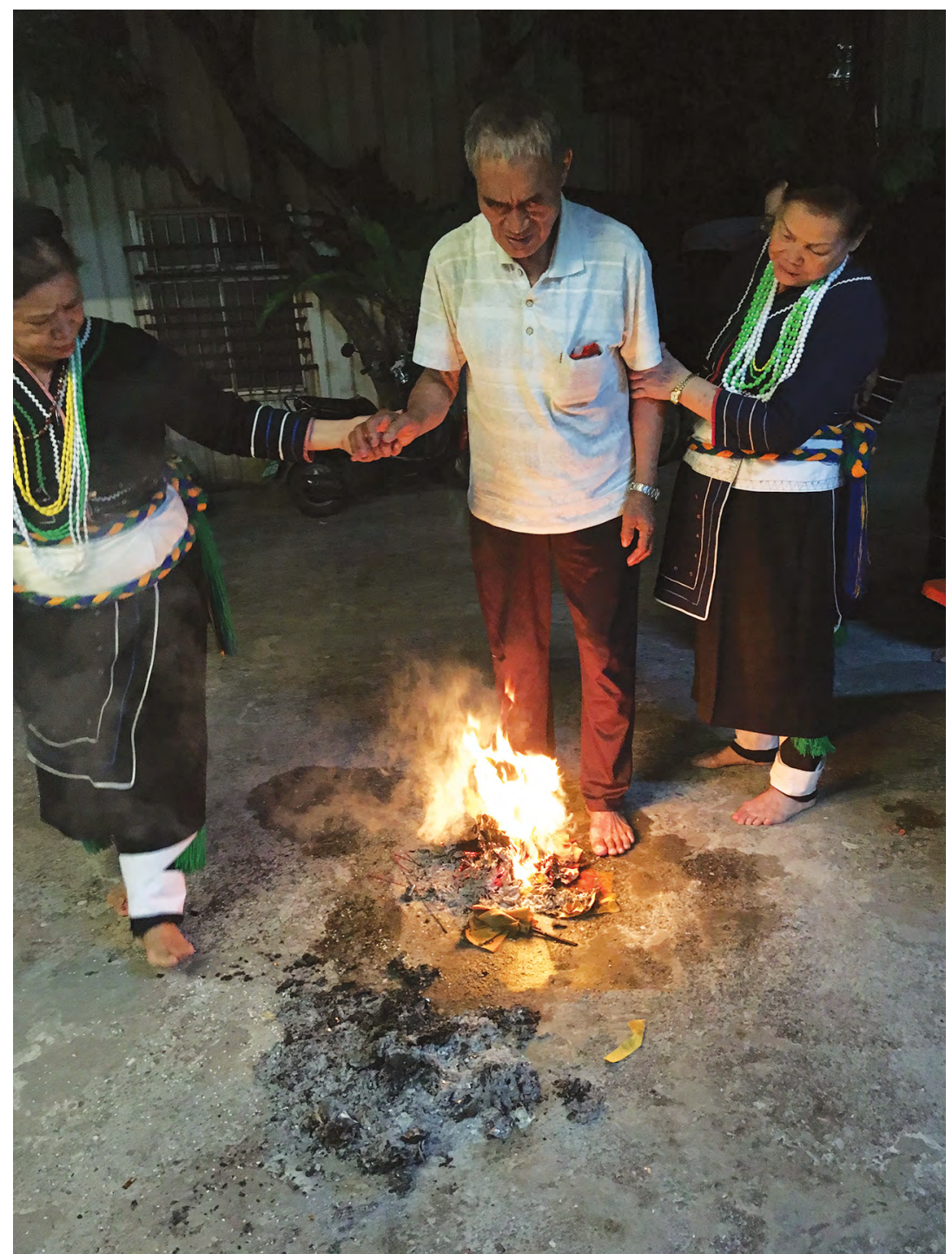

Plate 3.3 During the Mirecuk ritual, shamans help a crippled man hop over the fire stack to cure his problem leg

Photo: Yi-tze Lee. 


\section{Mivava: Sacred thread to distinct species of birds in the rice field}

The Amis believe that various spirits (kawas) dwell in different places in the world. When a person dies, he or she will go to a territory belonging to the ancestral spirits (duas). From here, the spirits of the dead regularly visit the living. Amis shamans are responsible for making possible communication between the living and the spirits of the dead. Lidaw village has the most comprehensive ritual practices among the Amis. There are about 200 days in the year that come under conditions of paising ('taboo'). Every household also intermittently needs a sikawasai for dealing with illness (badevu), giving offerings to the ancestors (ba-nanom), cleansing newly built houses (miasik) or hosting funeral rituals (misa-pangcah). Before a ritual can be carried out, villagers need to prepare a standard set of offerings: sticky rice or millet cake (toron), betel nut (icep), betel pepper (fila) and rice liquor (epa'). Depending on the purpose of the ritual, additional plants must also be prepared. A shaman sometimes even specifies the location and the direction from which these plants are collected. When everything is prepared, the shaman will rely on the power of these plants to ensure the effectiveness of the ritual. The calai - the symbolic road-is attached to the leaves of these plants.

A most important public ritual pair is Misatuligun (worship to the land deity) and Mivava (cleansing the field for rice cultivation) (see Table 3.2 for a comparison of private and public ritual settings). In these rituals, the calai shows its capacity to act as a path as well as a means of testing paths. In the past, Amis women cultivated open fields after the sowing of millet or rice. The shamans would perform a Misatuligun ritual to keep wild birds away and protect the rice seedlings and a Mivava ritual to dispel unruly pests. During the Misatuligun ritual, they would take the pieces of a taker from a linen bag and put them together. A taker is a hunter's bird trap made of bamboo sticks and a long linen circle. In the ritual, the shaman faces southward to pray to the dongi to obtain a calai. Once she has the calai, she knows the correct ways to the animal spirits and then aligns the symbolic calai on ginger leaves to each of their taker before attaching them at the southern ridge of the rice field. After a while, each shaman retrieves the taker and offers rice liquor because the kawas (spirits) of wild birds have been caught on the taker. After this, each shaman takes a piece of ginger leaf and throws it into the air to release the 'captured spirits'. 
A proper calai helps the sikawasai to specify possible wild birds during the ritual: sparrow (cirociro), drongo (tatacio), red-necked pheasant (trok), duck (koakoa) or brown shrike (cicale').

Table 3.2 Comparisons of items in family and tribal rituals

\begin{tabular}{|l|l|l|}
\hline Item & Family rituals (private) & Tribal rituals (public) \\
\hline Plants as ritual platform & Banana leaves & Silver-tail miscanthus \\
\hline Ritual vessels & Sifanohay (female ritual vessel) & Diwas (male ritual vessel) \\
\hline Ritual offerings & $\begin{array}{l}\text { Betel nut, betel pepper, rice } \\
\text { liquor, sticky rice cake }\end{array}$ & $\begin{array}{l}\text { All the elements for family } \\
\text { rituals, plus a rooster }\end{array}$ \\
\hline Spiritual protector & $\begin{array}{l}\text { Dongi (female spirits) to } \\
\text { provide calai }\end{array}$ & $\begin{array}{l}\text { Malataw in the mountains } \\
\text { and wild areas }\end{array}$ \\
\hline Ancestors in rituals & $\begin{array}{l}\text { Duas (ancestor spirits) of the } \\
\text { household }\end{array}$ & $\begin{array}{l}\text { Famous tribal leader, } \\
\text { chiefs, shamans }\end{array}$ \\
\hline
\end{tabular}

This shamanic performance is called Tala-omah and is an activity to draw spiritual power from loma' ('the household') to omah ('the field'), using ginger leaves linked to specific birds to catch them and prevent them eating the rice seedlings. The ritual space is transformed by driving bird spirits from the rice field. This in effect drives these birds from the rice field, which belongs to the female sphere, to the outside male sphere. This action of Tala-omah beautifully effects a transition from inner to outer, from plant to animal and from female to male (as ginger leaves are for female and birds are for male). The calai is the symbolic connection between these two worlds, where a path from the inner world leads to the outer world — a path channelled by the shaman's embodied action. During the ritual chanting of Mivava, the calai is used to distinguish migrant from resident birds. Only migrant birds are symbolically caught before releasing them again since these birds are a menace from the other world. Resident birds, especially pheasants or quails, are symbols of male age groups and therefore need to be protected from harm while in custody. ${ }^{8}$ The calai not only provides the path from the mundane environment to a sacred space; it also has the capacity to distinguish between different species in the Amis life world. The calai held by shamans are constantly tossed out and drawn back during the Mivava ritual to cleanse the territory and remake the boundary of the village. Through the active bodily movement of shamans, the calai are transformed from a healing and discriminating tool to a powerful symbol of protection.

8 Gender difference is a constant theme in shamans' creation of boundaries (Strathern and Stewart 2003) and is entangled in a multispecies agenda (Kirksey and Helmreich 2010). 


\section{Miasik: Path-finding negotiations and testing for authenticity}

Another ritual in which the calai serves as a path that must be tested is Miasik. The main purpose of the Miasik ritual is to cleanse a newly built or renovated house and to put away remaining construction materials to obtain good luck. In this ritual, a shaman requests a calai from the dongi spirits, holds the sacred calai in her hand and uses this invisible thread to 'scan' the whole house from inside to outside. For an Amis shaman, authenticity in ritual is critical. The correctness and quality of the calai from a guardian dongi need to be constantly examined in response to possible threats.

According to the sikawasai, the dongi are guardian deities in daily life, but they also guard and keep intact the purity of the ancestral world. A calai creates a mutual connection to both the mundane and the sacred worlds. After each ritual occasion, the calai has to be returned to the dongi and they have to be thanked for their generosity. There is a sense of care and cautiousness in dealing with each calai; it is the path between two worlds. The purity of the road is essential at both ends.

When the calai is transformed from a path to a cleansing tool, the authenticity and purity of the calai are doubly important. When a shaman acquires an invisible calai, it cannot be used directly. The ancestors can be mischievous towards their offspring and play jokes on their family if they have not carried out worship properly, but also the Han people, who have taught the Amis modern techniques for building houses, may have disguised the correct means of construction and inserted malicious spells into the house. In this case, the calai for the Miasik ritual will indicate the proper path to connect to the household ancestors, but also to connect with the non-indigenous Han technician deities. The calai thus embodies ambivalent relationships and historical memories between the colonised and the settlers' technological worlds.

During the Miasik, a shaman attaches the acquired calai to a place very different to the leaves used in a public ritual such as the Mivava. In this house-cleansing ritual, the right leg of a domestic pig is used as the means for cleansing as well as for blessing. The pig sacrificed in the ritual is shared with the participants, but only the shaman can consume the right leg since it is used as an embodiment of the calai. The use of a pig's leg 
as a calais vessel boosts the power of cleansing and blessing. 'Wrong or bad' calai-paths are also sought and questioned in case they are hidden in the construction materials such as nails, wire or wood blocks-items that need to be thrown out of the house at the end of the Miasik ritual. The test of a calais authenticity is performed by the shaman, who carries the leg to touch different parts of the house in the baceva process. As another example of baceva, when used in everyday bargaining conversations, the term means 'to check by cheating' or 'bluffing'. Baceva involves validating the genuineness of an expression or the authenticity of information. Calling someone baceva does not mean that he or she is a cheater, but rather seeks reassurance of the sincerity of the interlocutor as well as the moderation/mediation of someone who asks for help. ${ }^{9}$ Baceva during the Miasik ritual reflects the possibility of harm either from dissatisfied ancestors or from the colonisers' technological influences.

\section{Mirecuk: Body politics in the making of Amis orientations}

According to Amis traditional subsistence strategies, gender differentiation is embodied in household living spaces and the way in which the different tools used for daily activities are arranged in their respective spaces. The northeastern corner of a house is called the talofoan and is where pottery, cooking utensils and, especially, female ritual vessels or sifanohay are placed. This is an assigned female space. Diagonally opposite the talofoan is the cacaraian corner, at the southwestern side of the house. Cara refers to animals' mandibles and is applied to the corner of the house where men display their glorious hunting trophies. It is also the corner where men put their hunting tools and ritual vessels known as diwas. The northwestern corner is called the pafotingan and is where fishing nets and tools are placed. This is also a male corner. The southeastern corner is called pasaasikan and is where women's farming tools are stored. This household geomancy of sides and corners has latent rules that reflect male and female distinctions: the male sphere is at the western and northern corners of the house, while the female sphere is at the eastern and southern corners.

9 In Korean shamanic performance, the authenticity of a ritual practice also needs to be examined over and over again to prevent financial fraud and ensure the reliability of information flow (Kendall 2009). 


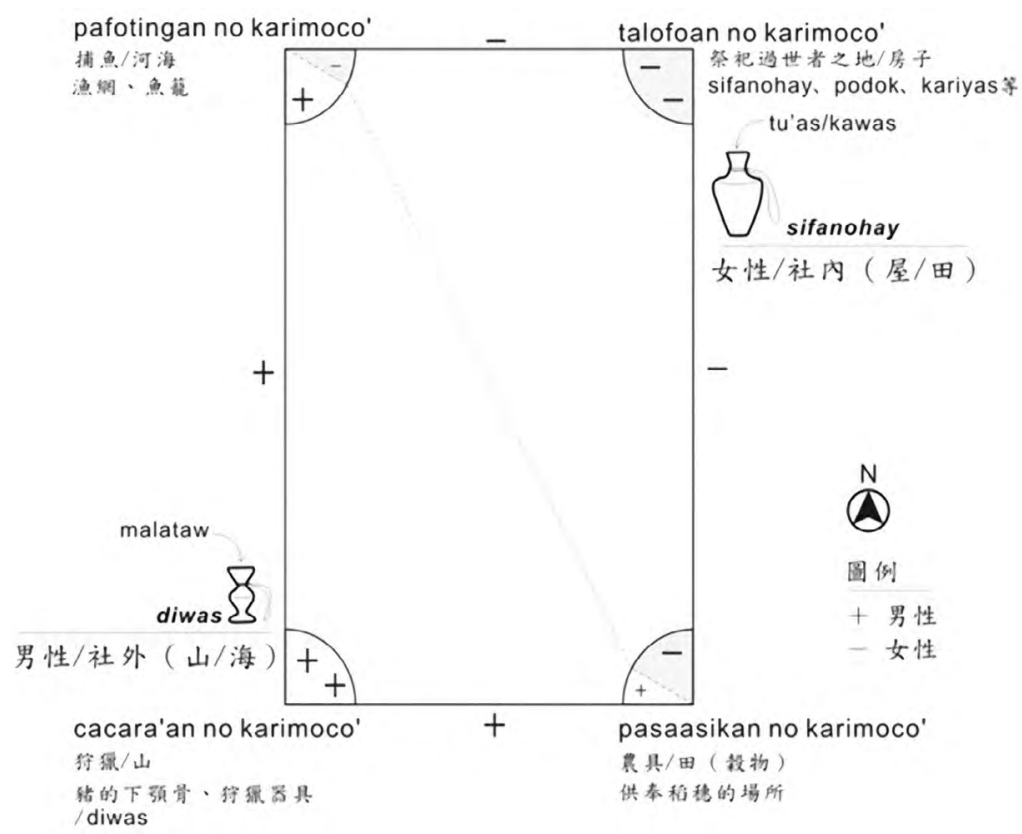

\section{Figure 3.2 Household orientations for the Nangshi Amis}

Source: Drawn by the author.

The directional opposition that associates males with the south and females with the north can be found in the funeral ritual as well as the Mirecuk ritual. Both rituals involve a process of regeneration and reunion with the kawas/duas ('spirits'/'ancestors'). The essential directions of this malefemale spatial opposition are the southwestern corner for males (where the mandibles of wild pigs are hung) and the northeastern corner for females (where the granary is placed). Mirecuk is the time for the rejuvenation of shamanic power. It takes place in late September when all harvest work has been finished. The main purpose of Mirecuk is to let shamans worship the spirits related to the illness that makes them shamans, and in this way to renew their spiritual power and connections. Each shaman who is based in a particular lineage and family traces an inherited connection to particular spirits. The whole of the day's ritual of Mirecuk is devoted to the historyladen and life-generating path to the realm of spirits. To journey to the realm of spirits, shamans have to ask for a calai as their lalan from their guardian dongi. This will guarantee the correct path to the spiritual world. Only by following the correct ancestral path is the connection to the benevolent spirits guaranteed. A misleading path can result in missing the spiritual realm and not returning to life in the mundane world. On this ritual occasion, the testing of the authenticity of the thread leading to the spiritual 
road is different from that in the Miasik ritual. In the house-cleansing ritual, the testing of authenticity is done through the shaman's dialogue with the spirit. The result is visible to those attending when the correct cala $i$ is tied to the right leg of the pig to bring forth the blessing. In Mirecuk, the shaman tests the authenticity of the path by constantly checking contact with the calai. The shaman who receives a calai from a spirit checks this contact not only by verbal assurances, but also by various movements in receiving and returning invisible threads. By waving and padding lightly on her body and by expelling signs of spiritual contact through coughing, crying and jumping up and down in a small circle, the shaman indicates that the calai is attached only to her hands and not to other parts of her body. Every entry into and exit from the invisible path requires a bodily examination to show the separation from the potentially harmful spirits.

Healing is a major activity practised during the Mirecuk ritual, aiming to boost the ritual power of individual shamans, and the 'patients' are the sikawasai shamans of the host and her family members, who are usually women. The other shamans will be the healers who request and test calai from different deities. The ritual is performed publicly and villagers can be guests to witness the ritual power. Since women are leaders of the Amis household and of their families, healing during this ritual of spiritual rejuvenation is focused mainly on women's bodies and their condition. In such cases, healing is carried out through the benign power of the calai. The process is called badevu, meaning 'to stitch and mend the body'. In the prayer before the healing action, the power of the dongi is invoked and the condition of the person is described:

Ato haw Haidan haw fayi haw!

Here, my great aunty! $!^{10}$

Sasurian dongi, Matiting dongi, Kakumudan dongi, Lalicayan dongi, Afuduay dongi!

You are the healer, person-maker, protector, gatherer, listener, with soft steps!

Saw anini sakirami haw a misuri hatini safadongi namo!

Yes, today there is a person who needs your healing power!

Haw ira suri satu kirami haw kamo matia tuni hulakan!

Please take away the pain and heal, just as you take off our clothes.

Aka baceva a lalan do kamay namo aka baceva bilimakimay.

10 Fayi means 'old lady' or 'aunt' in Amis, and faki means 'old man' or 'uncle'. Fayi is a term of daily address to older women. However, during ritual chanting, shamans use fayi to convey intimacy with the dongi spirits. 
Please do not give us the wrong path to tread, please guide our hand on the right location.

Haw pakalemeden miso kami maluina lemed tini acay kirami haw na misuri namo to kalimakimay ku maidama.

The one we need to heal is like a mother and child to you. Please cure her and let us benefit from your power by doing so.

Sa'hini sahanaca $i$ tamuan minaor tu lingalawa, yia!

Please take this spirit/offering first so we can share later!

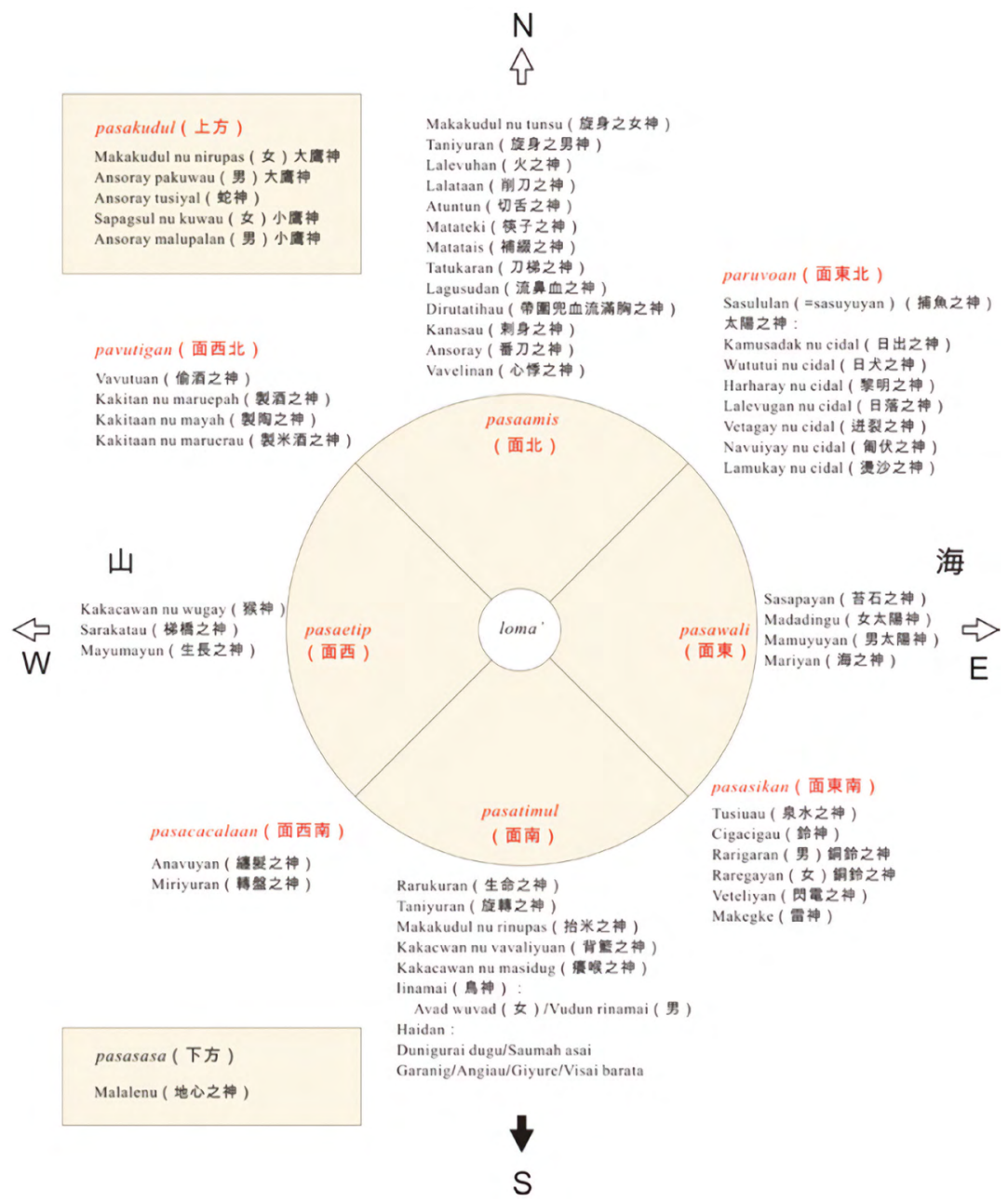

Figure 3.3 The major spirits (kawas) Amis shamans encounter during the Mirecuk ritual. As well as the eight directions on the plane, there is also a pasakudol (upper level) and a pasasaan (underground level)

Source: Butal et al. (2009: 112). 
In the process of praying and chanting, Amis shamans use special terms to ask the guardian dongi spirits not to direct them on a wrong path or lead them to the wrong destination. The shamans repeatedly check and clear the calai while they remind and reassure the spirits about their faith in them and their need to obtain the right tool and set out on the right path. In some cases, this constant need for reassurance may seem strange since the dongi are guardian spirits. In most cases, however, these requests are a constant reminder that the Amis who have migrated along traditional routes and live in an ever-changing environment are conscious of their need for symbolic healing. Like the conflicts and conundrums revealed in modernised magic (Meyer and Pels 2003), the Miasik ritual reveals the caution the Amis have regarding the construction techniques they have learned from other ethnic groups; it also reflects the constant tension between requests directed to the guardian spirits and the possible loss of their protection without warning.

The banter involved in baceva is expressed modestly to prevent the spirit becoming jealous. The same attitude is adopted towards family members as well. During the final session of the Mirecuk, the eldest son of a sikawasai told me:

During the ritual session, every conversation and action is monitored by the ancestors, and if we talked about the exact time of doing something, the ancestors would mock our pride and send malicious tricks to us. Baceva is to let the spiritual beings think that we don't know the correct way and need to be taught again in our ritual preparation.

This comment shows the importance of baceva to the shamans and ritual participants. Baceva reflects a human-spirit connection in a restrained way: knowing the correct practice in a ritual process is one thing, but showing the right timing is another. Baceva creates a space for authenticity testing of both belief and behaviour. Verbally, shamans comply with the rules of baceva to show their discipline. Physically, they need to check all the calai that are given from the spiritual world, using these magical threads to cleanse, sweep, pad, expel and carry out other actions to distinguish good from evil. By so doing, shamans deploy their bodies within the symbolic boundaries set by the calai. This constitutes the ritual politics of the body. 


\section{Path and testing: The embodiment of changing ritual relations}

In the rituals of Mivava, Miasik and especially Mirecuk, the importance of the calai as a symbolic path whose authenticity requires testing evokes a ritual landscape that is substantially represented in embodied experiences (Csordas 2002). This is the environment in which Amis elders still live. Through their bodily performances, shamans carry out various processes of negotiation in acquiring and examining paths. The shaman's body, the ginger leaves the shamans hold and the pig's leg all become vessels for the symbolic calai-path that is given by the spirit. Only a physical body can provide substance for the path that is created. ${ }^{11}$ My argument is that the authenticity of a path can only be recognised through this embodiment. Through the shamanic bodily performances of constant checking, examining and verbally providing assurances, a calai is transformed from an imaginary thread to a powerful tool of ritual efficacy.

A calai represents the 'road' or 'path' that is signified. The signifying process is by no means simple. There may be misleading ways, unsuitable materials and mistaken actions. As a consequence, each symbolic road needs to be examined and the objects found along it interrogated over and over again during the ritual process. While the rituals led by Amis shamans may reveal the basic infrastructure of the spiritual world, the movements and actions in this ritual space are still negotiated via bodily gestures and cautious steps along this symbolic calai-path. It is said that, in the past, male shamans were more aggressive. They negotiated forcefully and tried to persuade the dongi to give a better calai sooner. Nowadays, only female shamans perform these rituals, using their negotiating skills and bodily movements to gain the right path. Today, no male shamans practice in the Nangshi area. Instead, men work outside the village and cannot (or will not) observe the necessary dietary restrictions; men are also in contact with more unreliable and potentially dangerous outsiders in their daily activities than are women. Male villagers have abandoned more of their traditional activities than women, and therefore are less capable than

11 Scheper-Hugh and Lock (1987) use the idea of the 'mindful body' in their exploration of medical anthropology and delve into the issues of bodily phenomena as the arena of ideological power struggles. This concept also resonates in the realm of religion where the body is the locale of power relations between humans and spirits. 
before of 'arguing' a case in the rituals. Women's negotiation style with the dongi spirits for the correct calai reflects the feminising of participation in contemporary Amis society.

In this chapter, I have tried to indicate the sustainable adaptation of ritual activities. These activities create local memories and an appreciation of paths defined by calai. External forces have affected the performance of Amis rituals. Changing subsistence strategies have affected the shaman's field ritual of catching symbolic birds in Mivava. Urbanisation and modernity have led to contested ways of living and have changed key elements in house construction that require purification by groups of shamans in Miasik. Verbal and bodily performance require tentative examination of the ritual pathway and boundaries for ancestral recognition in Mirecuk. Ritual is where memories are created and Amis society is reshaped.

\section{References}

Butal, Aits, Gene-Sheng Tung and Yi-tze Lee. 2009. Pangcah Miaraw: The ethnobotany of Amis in Eastern Formosa. Taipei: Forestry Bureau, Council of Agriculture, Taiwan.

Csordas, Thomas. 1990. 'Embodiment as a Paradigm for Anthropology.' Ethos 18(1): 5-47. doi.org/10.1525/eth.1990.18.1.02a00010.

Csordas, Thomas. 2002. Body/Meaning/Healing. Contemporary Anthropology of Religion series. New York: Palgrave Macmillan. doi.org/10.1007/978-1137-08286-2.

Hu, Jackson. 2007. 'The articulation of modern fetishisms and indigenous species.' Taiwan Journal of Anthropology 5(1): 1962.

Ka, Chi-Ming. 1995. Japanese Colonialism in Taiwan: Land tenure, development, and dependency, 1895-1945. Boulder, CO: Westview Press.

Kendall, Laurel. 2009. Shamans, Nostalgias, and IMF: South Korean popular religion in motion. Honolulu: University of Hawai' i Press. doi.org/10.21313/ hawaii/9780824833435.001.0001.

Kirksey, Eben and Stefan Helmreich. 2010. 'The emergence of multispecies ethnography.' Cultural Anthropology 25(4): 545-76. doi.org/10.1111/j.15481360.2010.01069.x. 
Liu, Pi-chen. 2007. 'Rice, deer and rooster: Foods, power and gender symbols among the Kavalan of Taiwan.' [In Chinese]. Taiwan Journal of Anthropology 67: 43-70.

Lo, Su-mei. 2010. 'Cultural identity, ecological conflict, and ethnic relations: On the discourses of traditional territory of Atolan Amis.' [In Chinese]. Journal of Archaeology and Anthropology [Taiwan] 72: 1-34.

Meyer, Birgit and Peter Pels. 2003. Magic and Modernity: Interfaces of revelation and concealment. Stanford, CA: Stanford University Press.

Scheper-Hugh, Nancy and Margaret M. Lock. 1987. 'The mindful body: A prolegomenon to future work in medical anthropology.' Medical Anthropology Quarterly 1(1)(NS): 6-41. doi.org/10.1525/maq.1987.1.1.02a00020.

Strathern, Andrew and Pamela Stewart, eds. 2003. Landscape, Memory and History: Anthropological perspectives. London: Pluto Press.

Tsurumi, E.P. 1977. Japanese Colonial Education in Taiwan, 1895-1945. Cambridge, MA: Harvard University Press. doi.org/10.4159/harvard.978067 4434080 . 
This text is taken from Austronesian Paths and Journeys, edited by James J. Fox, published 2021 by ANU Press, The Australian National University, Canberra, Australia.

doi.org/10.22459/APJ.2021.03 